\title{
Os Parques: Velhas Idéias e Novas Experiências
}

Vicente Quintella Barcellos

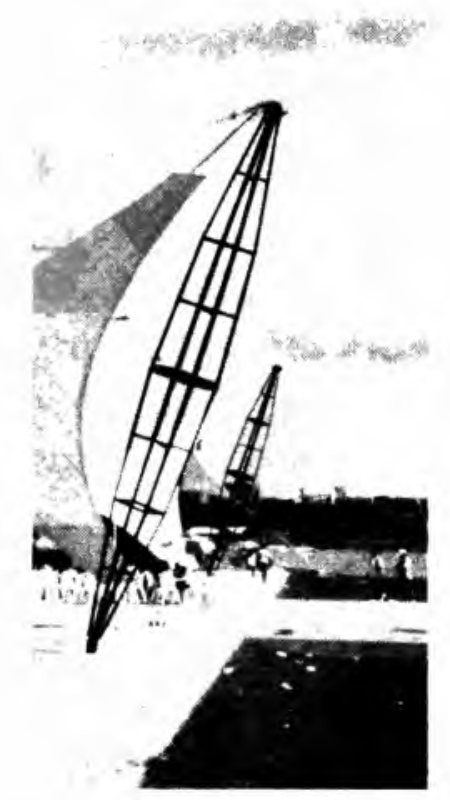

Paisagista, arquiteto e urbanista, mestre, doutor, pesquisador e professor da área de Arquitetura da Paisagem dos cursos de graduação e pós-graduação da Faculdade de Arquitetura e Urbanismo da Universidade de Brasilia

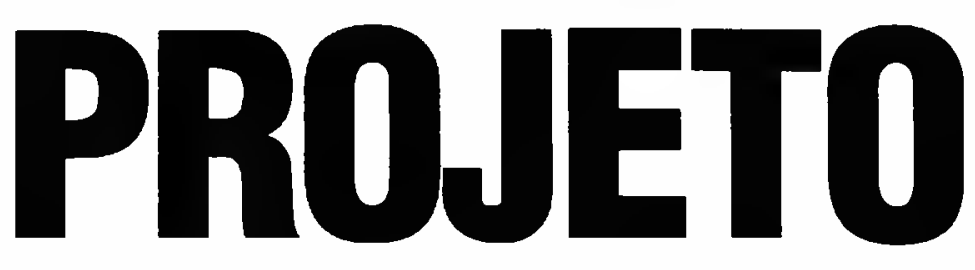


Em sua evolução histórica os parques têm assumido diferentes configurações e distintos significados sociais. Recentes transformações econômicas e culturais têm produzido alterações no modo de se tratar a questão do parque público nas cidades brasileiras. Por um lado, mudanças comportamentais têm revigorado o uso dos parques pelas populações urbanas, por outro lado novos papéis têm sido atribuídos aos parques pelos agentes envolvidos nos processos urbanos. Nesse sentido podem ser identificadas duas vertentes de ação influenciando o modo de se tratar a

Uل questão. Na primeira tem-se o uso dos parques nas estratégias de conservação ambiental, e na segunda, como elementos de dinamização da economia urbana. Pela análise dos casos dos parques de Curitiba e do Projeto Orla de Brasília, exploram-se algumas das implicações desses novos modos de encarar os parques públicos no contexto das cidades brasileiras.

\section{"The new role of the Public Park: The Brasilia Shore Project and the} Curitiba Parks case". In their historical evolution, the parks have assumed different configurations and distinct social meanings. The current cultural, social and economic changes have been created new ways of facing the public park issue in the brazilian cities. For one side, behaviour changes have been reinvigorated the use of the parks by urban population. And on the other side, new roles have been attribuited to the parks by involved agents in the urbanization processes. In this way, can be identified two paths of actions, influencing the way to face the issue.

(n) First, you have the use of the parks in the strategics of the environmental m conservation and second, dynamic elements of urban economy.

Throughout The Brasilia Shore Project and the Curitiba parks case analysis, explores the implication of this new way of facing the public parks.

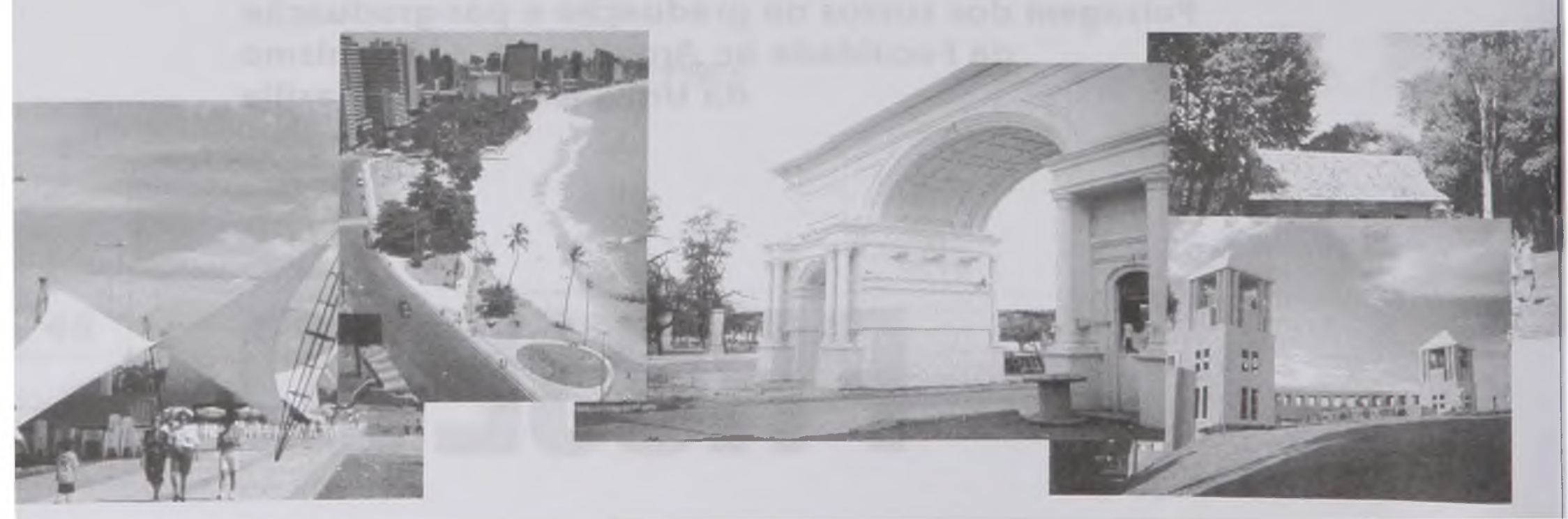




\section{Os Parques: Velhas Idéias e Novas Experiências}

Desde o seu aparecimento nas cidades, o parque' tem passado por grandes transformaçōes, tanto em seu significado social quanto em sua configuração físico-espacial. Durante todo o século 20, mas especialmente a partir das décadas de 60 e 70, a velocidade dessas transformaçōes se acelera, exigindo dos profissionais que atuam na paisagem a revisão dos pressupostos usados na definição do conceito de parque público. No contexto brasileiro, essa revisão reveste-se de importância, na medida em que predomina a tendência de reduzi-lo a uma imagem que em muitos casos está superada, situação esta que dificulta a compreensão dos novos papéis que os parques estão assumindo nas cidades ${ }^{2}$

Em descompasso com essas novas experiências, muitos profissionais continuam a conceituar o parque público com base no ideal do parque paisagístico, cujo modelo, depois de ter sido desenvolvido na Inglaterra é reelaborado nas cidades européias e chega ao Brasil ${ }^{3}$. Nessa visão, a paisagem pastoral criada por Frederick Law Olmsted em meados do século 19, no Central Park de Nova York, hoje cercado de arranha-céus, com suas grandes massas de árvores, extensos gramados e lagos, seria o protótipo do parque.

Nessa visão, os parques são entendidos exclusivamente como espaços livres de grandes dimensōes em que predominam os elementos naturais, em cujo interior as massas edificadas da cidade apenas são percebidas de modo atenuado, num difuso plano de fundo. Predomina ainda entre nós a idéia do parque como um pulmão verde, ou um fragmento da natureza, que se contrapõe à cidade e com a qual mantém poucas conexōes, numa concepção que se aproxima daquela dos movimentos higienistas do século passado que apoiavam a criação de parques nas cidades européias, como meio de combater as mazelas urbanas provocadas pela Revolução Industrial.

(1) O parque é conceituado no âmbito desse trabalho como um espaço livre público destinado ao lazer e à recreação. embora outros importantes usos e finalidades possam estar a eles associados, como por exemplo, as de conservação ambiental. Tal conceituação parte do princípio de que, enquanto usos de lazer, nas suas variadas manifestaçōes, são uma constante ao longo da história dos parques. Desde sua origem eles têm assumido diferentes características físico-espaciais, e adquirido diferentes significados sociais.

(2) Anteriormente, Galender (1992, p.113-120) e Barcellos (1996, p.153-160) já chamaram atenção para esse problema.

(3) A introduçāo da idéia do parque paisagístico no Brasil foi feita por Glaziou, ao reformar o Passeio Público do Rio de Janeiro em 1861, o que se explica pelo fato de ele ter participado da equipe de Alphand que reformou Paris, entre 1850-1860, e construiu vários parques usando o mesmo modelo. 


\section{Velhas Idéias}

Dois aspectos são importantes nesse modo de conceituar os parques públicos. O primeiro diz respeito à imagem do parque como espaço livre que se caracteriza por ser predominantemente ocupado por massas de árvores e outros elementos naturais. O segundo diz respeito à relação de contraste entre as massas edificadas da cidade e o ambiente natural do parque assim concebido. Como conseqüência, tudo que se afaste dessa idealização costuma não ser considerado parque.

Nesse sentido, o parque é quase sempre definido como uma antítese da praça que, em sua configuração vernácula, é arquitetonicamente constituída e integrada à malha urbana. Portanto, com características físico-espaciais opostas àquelas que se costuma atribuir aos parques.

Mas na realidade, esse é apenas um arquétipo que nos remete às configurações das praças da Idade Média ou do Renascimento. Mesmo porque, já desde o século 18 nas cidades européias (e um pouco mais tarde nas cidades brasileiras), quando a burguesia mercantilista se faz hegemônica, surgem novas tipologias de praças e a antiga praça passa a ser arborizada e ajardinada, inclusive como meio de eliminar as barracas de vendedores de rua, bandos de acrobatas e outras formas de comércio e manifestações populares que passam a ser consideradas indesejáveis. Descrevendo essas mudanças, Richard Sennet diz que, a partir daí, a praça de uso múltiplo passa a ser consumida "pelo espaço tomado como um monumento a si mesmo ou como um museu da natureza em meio ao mais sofisticado tipo de moradia" "4

Nessas transformações dois aspectos devem ser ressaltados. O primeiro diz respeito à progressiva eliminação da multifuncionalidade que caracterizava a praça e dá lugar ao elegante passeio e à contemplação. O segundo diz respeito à introdução da vegetação nas praças, alterando as condições de percepção dos espaços livres do observador, embora a força dessa alteração seja variada e dependente das dimensões dos espaços, da intensidade da arborização e do estilo adotado. No caso dos traçados inspirados na geometria do jardim barroco de parterres, os eixos daí resultantes abrem perspectivas que possibilitam a visão das fachadas dos prédios do entorno, fazendo com que a idéia de praça não se desfaça totalmente. O mesmo não ocorre com as praças resultantes da transposição do traçado do parque paisagístico de formas sinuosas que simulam românticos bosques.

Nas cidades brasileiras, esse processo apresenta especificidades, mas ao seu tempo, os espaços livres remanescentes do período colonial, antigos terreiros, largos e praças que até então guardavam o chão limpo de terra batida, da segunda metade do século 19 em diante, passam a ser ajardinados. Segundo Murilo Marx, "o sucesso dessa transformação foi tal que logo se perdeu a noção das peculiaridades (...) de uma praça"

(4) SENNETT (1998, p. 74-78).

(5) MARX (1980, p. 61-67). 
Por outro lado, os parques têm assumido reduzidas dimensões. Isso, além de contrariar aquelas concepções que o associam a grandes espaços livres, faz com que as eventuais diferenças com relação às praças se tornem insignificantes. Mas, ao contrário do que costumamos pensar, a ocorrência de parques de pequenas dimensões não é um fato recente. Exemplo disso é o Passeio Público do Rio de Janeiro, considerado nosso primeiro parque, cujas dimensões são inferiores a muitas praças, embora tenha sido criado numa área que na época era periférica à cidade.

De fato, o surgimento de parques de pequenas dimensões só se intensifica nas primeiras décadas do século 20, principalmente no contexto das tumultuadas cidades americanas que se industrializam sob impacto dos fluxos migratórios. Aí, uma confluência de movimentos sociais, que entende a recreação ao ar livre como instrumento de socialização e aglutinação comunitária, coloca na pauta de suas reivindicaçōes políticas a criação e a organização dos parques nas cidades, fazendo com que eles passem por radicais transformações: seu tamanho é reduzido para que possam ser disseminados próximos aos locais de moradia e trabalho e a ilusão pastoral é abandonada. A vegetação, quando não é totalmente eliminada para dar lugar a caixas de areia, brinquedos e quadras para as diversas modalidades esportivas, comparece apenas como pano de fundo ${ }^{6}$ (Foto 1). Quando nos anos 50, a organização de sistemas de

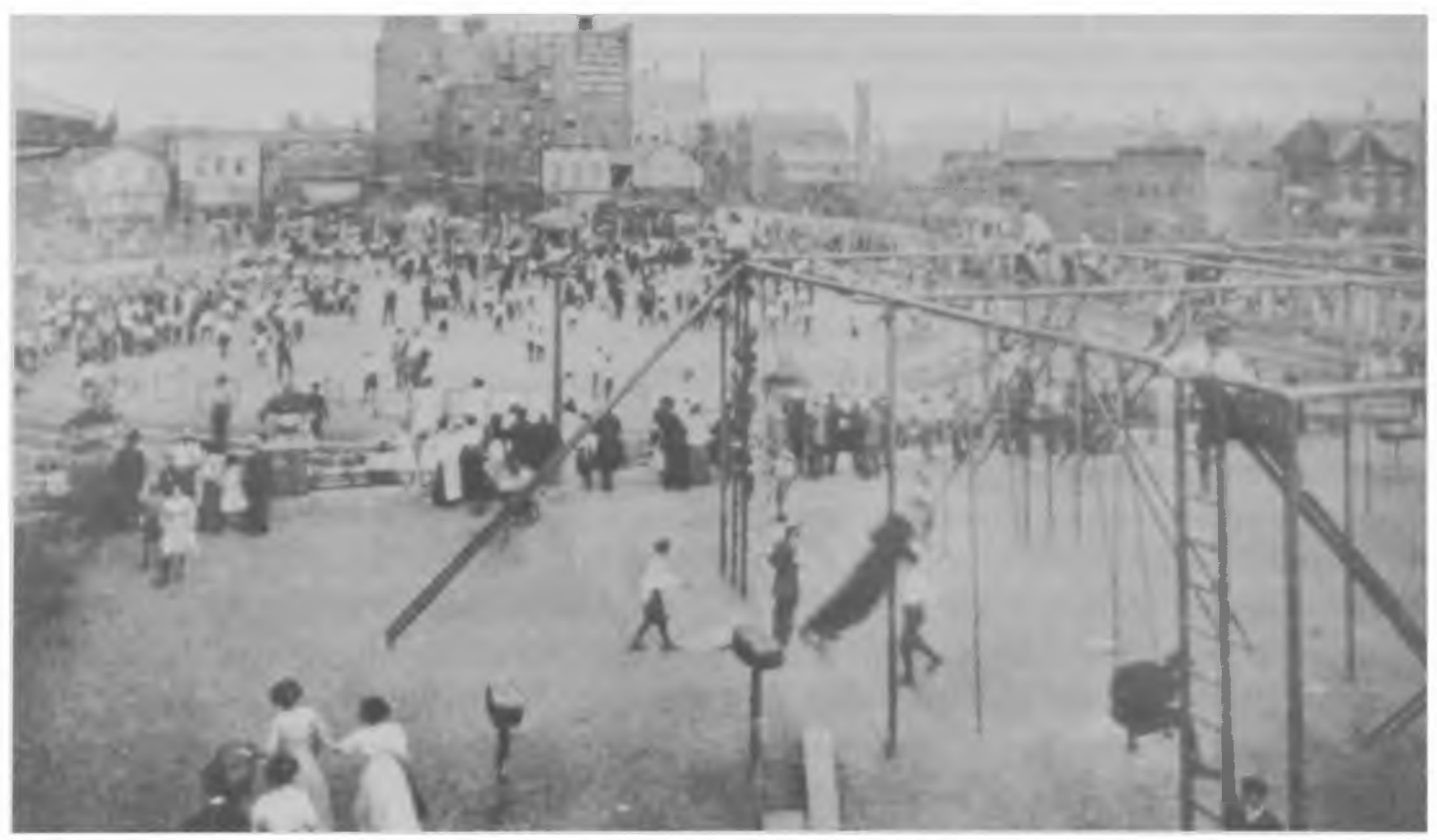

Foto 1: Stanford Park, Chicago, 1915. No início do século 20, nos Estados Unidos, os parques passam por radicais transformaçōes. A ilusão pastoral tende a ser abandonada. Em alguns casos, a vegetação é eliminada para dar lugar a quadras esportivas, brinquedos

Fonte: CRANZ, G. 1991, p. 120

(6) CRANZ (1991, p. 18-123). 
parques no contexto americano consolida-se - resultado de um continuado processo de planejamento que não se limita à escala urbana, mas engloba a região - surgem os minúsculos play-lots, solução encontrada para resolver os problemas da oferta de parques em áreas urbanas densamente edificadas, experiência de sucesso que foi repetida em outros países (Figura 2).

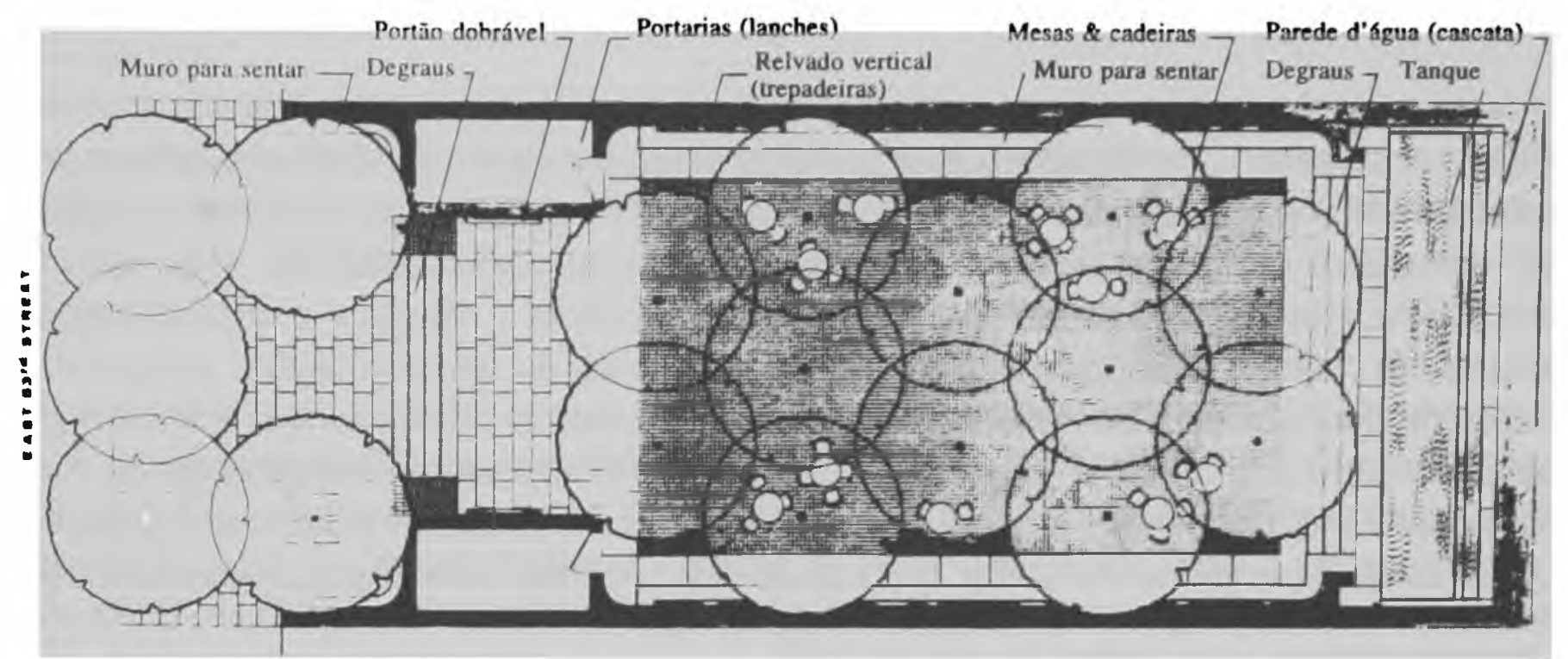

Figura 2: Paley Park, Nova York. Como meio de ser disseminado nas cidades, o tamanho dos parques é reduzido, dando origem a novas tipologias de parques. Seu sucesso inspirou uma série de versóes de play-lots lou pocketparks/ em muitas cidades, ao redor do mundo

Fonte: SPIRN, A. W. 1995, p. 91

Diferente do que ocorre nos países desenvolvidos, no contexto brasileiro a questão do lazer e da recreação nos espaços livres nunca foi objeto de políticas públicas - mesmo porque o atendimento dessas necessidades quase sempre não é percebido como uma obrigação do poder público. A organização de sistemas de parques nas cidades fez poucos progressos ${ }^{7}$ Só a partir dos anos 60, passa-se a observar algumas iniciativas com relação à questão do lazer $e$ da recreação pública. Evidentemente que não é nada comparado ao que ocorre no contexto americano em que existe uma tradição de políticas públicas para o setor, mas sim de iniciativas que, na maioria das vezes, são esporádicas e pontuais, beneficiando uma ou outra área urbana. A inauguração do Parque do Ibirapuera na cidade de São Paulo, em 1954, e do Parque do Flamengo no Rio de Janeiro, no início dos anos 60 , são exemplos de iniciativas de grande significado e apelo popular que, entretanto, não tiveram desdobramentos nas cidades em que foram executadas nem foram repetidas em outras cidades. Quando muito, estimularam a reforma de alguns parques e contribuíram para a disseminação de playgrounds e de outros equipamentos de

(7) "Colaboram para isso dois vetores de concepçōes (...). O primeiro de caráter imediatista, embasado na idéia de um desenvolvimento sem maiores consideraçōes pelas demandas sociais, em que o parque (...) representa apenas um custo que pode ser desconsiderado. Num segundo plano, pode-se considerar que essa percepção pouco favorável ao surgimento dos parques foi contraditoriamente alimentada por uma valorização ideológica do trabalho, que tendia a reduzir os parques a simples instrumento de reconstituição da força de trabalho a serviço da burguesia. "BARCELLOS (1999, p. 61). 
recreação em algumas praças de áreas residenciais, em geral, naquelas áreas urbanas de maior visibilidade para a população e, portanto, que ofereciam maior retorno político para os administradores responsáveis por tais iniciativas.

Mas essa introdução dos equipamentos de recreação nas praças, segundo Macedo, coincide com o momento de ruptura dos padrōes de desenho elaborados pelo ecletismo e sua substituição pelos padrōes do modernismo, ao mesmo tempo que fez com que as praças assumissem a função de locais de lazer e recreação paras as populações situadas no seu entorno ${ }^{8}$ Evidentemente que nas áreas centrais, elas mantiveram suas funções de espaço cívico e simbólico, embora pareçam passar por uma regressão que as levam de volta ao passado, já que têm sido tomadas por vendedores de rua, desocupados e toda sorte de marginalizados do processo social, fruto das continuadas crises por que têm passado o país. Ainda assim, pode-se afirmar que, pelo menos nas áreas residenciais, as praças assumiram algumas funções que antes eram reservadas aos parques.

Por isso tudo, tentar entender o parque usando o expediente de contrapô-lo à praça parece sem sentido, devido à multiplicidade de expressões formais e espaciais que as praças e os parques têm assumido, o que faz, como observa com precisão Galender, com que as denominações empregadas tenham um caráter, muitas vezes, arbitrário e portanto, restritivo, já que dificultam o entendimento dos novos fenômenos espaciais que estão ocorrendo nas cidades ${ }^{9}$

\section{Novas EXPERIÉncias}

Desde a abertura ao público das primeiras reservas reais na Europa até os dias de hoje, o parque tem assumido diferentes configurações físico-ambientais e distintos significados sociais ${ }^{10}$ Ainda que variando em intensidade, seu uso como espaço livre público de lazer e a presença dos elementos naturais parecem ser os únicos aspectos que se mantêm constantes ao longo do tempo e que podem caracterizá-los de modo adequado, principalmente quando se considera algumas de suas mais recentes experiências.

De fato, as transformações sociais, econômicas e culturais dos últimos 30 anos têm imprimido uma nova dinâmica aos parques. Se por um lado as mudanças comportamentais revigoram os parques como espaço de lazer e recreação pública ao aglutinar novos significados de uso, por outro lado, novos papéis passaram a ser atribuídos aos parques nos processos urbanos.

O Parque La Villete, construído nos limites de Paris, numa área que passava por acelerado processo de deterioração a partir de meados dos anos 80 e só concluído no final dos anos 90 , é uma experiência que sugere novos rumos na relação do parque com a cidade.

(8) MACEDO (1998, p. 13).

(9) GALENDER (1992, p. 113-120).

(10) Sobre a evoluçāo histórica dos parques, ver BARCELLOS (1999, p. 38-67). 
Obra do arquiteto Bernard Tschumi que o definiu como um parque do século 21, voltado mais às atividades culturais que ao repouso e ao relaxamento, e que na sua opinião haviam sido as "metas dos parques dos séculos 18 e 19" 11 o La Villete representa uma profunda ruptura com toda a experiência anterior, em especial, com todo o ideário do parque paisagístico.

Sua inovação tem sido definida por alguns autores ${ }^{12}$ em termos de uma atitude mais positiva com relação à cidade, que se expressa numa recusa de introduzir no parque a habitual atmosfera pastoral. Atitude que deve ser entendida dentro do contexto de superação do paradigma modernista quando arquitetos e urbanistas passam a abandonar certas percepções negativas com relação à cidade, as quais reforçavam o sentido anti-urbano dos parques. Em função disso, o La Villete foi concebido como espaço de aglutinação social voltado para as atividades culturais, onde a presença da vegetação é bastante reduzida. Como única concessão ao modelo tradicional de parque do século 20 , ele oferece apenas alguns brinquedos de formas inusitadas, mas as quadras esportivas estão ausentes.

No lugar da vegetação, grandes estruturas (dois pontilhões e uma extensa passarela coberta), junto com pequenas construções vermelhas em forma de cubos (as folies), rigorosamente alinhadas, destinadas a variadas finalidades (clubes musicais, escolinhas de arte, lanchonetes, banheiros etc.), funcionam como elementos organizadores dos espaços livres. Além dessas construçōes, encontram-se no parque cinco outras grandes construções: um centro de música e dança (Citté de la Musique), um museu de ciências (Citté des Sciences et des Techiniques). uma sala esférica de projeção cinematográfica (Géode), um teatro de múltiplas finalidades (Zénith) e um grande salão de exposições (Grande Halle). A exceção deste último edifício que data do século passado, o tratamento dado aos espaços livres do parque e às demais construções sugere uma pretensiosa exibição de tecnologias e materiais (Foto 3).

Em contraposição à idéia do parque paisagístico de construir uma paisagem pastoral e dissimular a cidade como meio de favorecer a experiência individual com os elementos naturais, o La Villete explora as conexões visuais com a cidade, abandonando a idéia da descontinuidade entre o parque e o tecido urbano e, como alternativa, oferece a possibilidade da experiência coletiva das atividades culturais, tendo como pano de fundo a cidade.

Ainda que pese a originalidade do La Villete, não há como negar no seu projeto um sentido de contraposição ao sucesso do parque temático americano - criação da era das histórias em quadrinhos e da televisão - sentido esse que faz com que Otilia Arantes o descreva como uma Disneyworld d̀ francesa voltada à alta cultura ${ }^{13}$. Mas, ainda segundo a autora, a construção do La Villete não é um fato isolado em si mesmo, ele integra um conjunto de grandes projetos pensados para revalorizar e revitalizar o centro histórico de Paris e fazê-lo reassumir o lugar de

(11) TSCHUMI apud MARTIN (1991, p. 268).

(12) Por exemplo: CRANZ (1991, p. 118) e COSTA (1993, p. 87-88).

(13) ARANTES (1993, p. 160). 


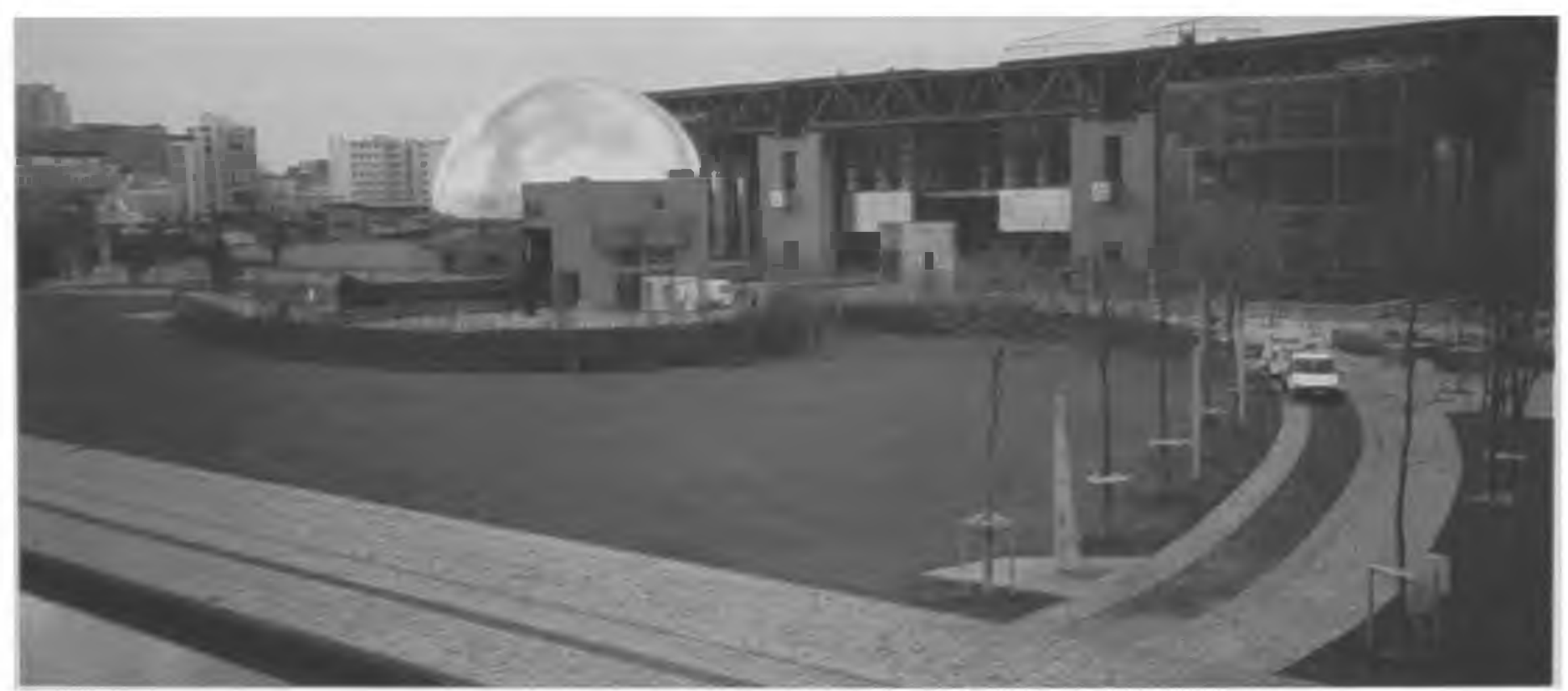

Foto 3: La Villete, Paris. Sua inovação tem sido definida em termos de uma atitude mais positiva com relação à cidade, que se expressaria numa recusa de introduzir no parque a habitual atmosfera pastora. Na foto, o edifício da Citté des Sciences e des Techniques com o Géode

Fonte: ZOPPI, M. 1996, p. 29

Capital Internacional da Cultura, como o Beaubourg, o Grand Louvre com sua polêmica pirâmide, o arco-monumento da Tête de La Défense, a Ópera da Bastille, o Museu d'Orsay, o Instituto do Mundo Árabe, a Biblioteca Nacional da França e outras grandes obras. Todas as obras assinadas por renomados arquitetos do star system internacional, que viraram sucesso de crítica e de público, e logo se transformaram em fluente destino turístico.

Para compreender o significado da proposta do La Villete, do mesmo modo como das demais intervenções urbanas, é preciso entender que ela se inscreve num movimento mais amplo, que surge da crítica à arquitetura e ao urbanismo modernista e marca uma guinada nos modos de se entender as cidades, movimento esse que teve na França um dos seus mais fortes focos de irradiação, mesmo porque aí os arquitetos e urbanistas viviam de modo mais intenso o impasse entre as necessárias políticas de conservação do patrimônio urbano e as políticas modernizantes do pós-guerra e seus fiascos ${ }^{14}$ Deriva daí a preocupação de se inserir o La Villete como elemento de revitalização urbana que busca uma nova relação com o legado urbano do entorno, ainda que sem abrir mão das inovações que marcam o contraste do antigo com o novo, numa atitude que procura renovar uma área deteriorada pela dinâmica dos processos urbanos.

(14) O mais conhecido exemplo desses fiascos é Sarcelles, que assim como outros grandes conjuntos habitacionais construídos nos subúrbios de Paris, dentro das concepçōes do movimento modernista que resultaram em ilhas de segregaçāo, tanto em termos sociais como construtivos, o que segundo a crítica que se passa a fazer depois dos anos 60, era produto de uma concepção que desconsidera o contexto em que eles se inseriam, já que partiam do princípio que as soluçōes poderiam ser universalizadas. 
Embora o La Villete permaneça único por seu caráter de parque voltado às atividades culturais, iniciativas semelhantes, pensadas a partir desses novos modos de se entender as cidades e com a preocupação de revitalizar periferias de núcleos urbanos, tem feito surgir mundo afora uma nova modalidade de parque - o waterfront ou o parque litorâneo.

Esse também não é um local para as práticas recreativas esportivas ou para a interação introspectiva com os elementos naturais, mas para o footing e o desfrute de vistas panorâmicas que, em essência, são urbanas. Fruto do casamento entre o interesse do mercado e o interesse público lgeração de postos de trabalho, renda e impostos) e pensado como ponto turístico e para aquelas formas de lazer mais comerciais, seus espaços costumam ser marcados por quiosques, cafés, finos restaurantes, lojas de lembranças e butiques. Aí, o papel das árvores e ajardinamentos é restrito, funcionam apenas como elementos de composição que permeiam os espaços livres.

Em variadas versões, eles aparecem em cidades tão distintas como Nova York, San Francisco. Vancouver, Cidade do Cabo e Buenos Aires, como meio de recuperar trechos de decadentes áreas portuárias ou industriais.

Algumas dessas modalidades de parques litorâneos, como os calçadões de orla, comuns na maioria das cidades litorâneas brasileiras, são resultado de intervenções remodeladoras que visavam a melhoria da qualidade dos espaços públicos à beira-mar, mas sem a pretensão de produzir maiores transformações, seja nos usos da população, seja na economia urbana (Fotos 4 e 5). Em outros contextos, eles assumem o caráter de verdadeiras operações urbanísticas.
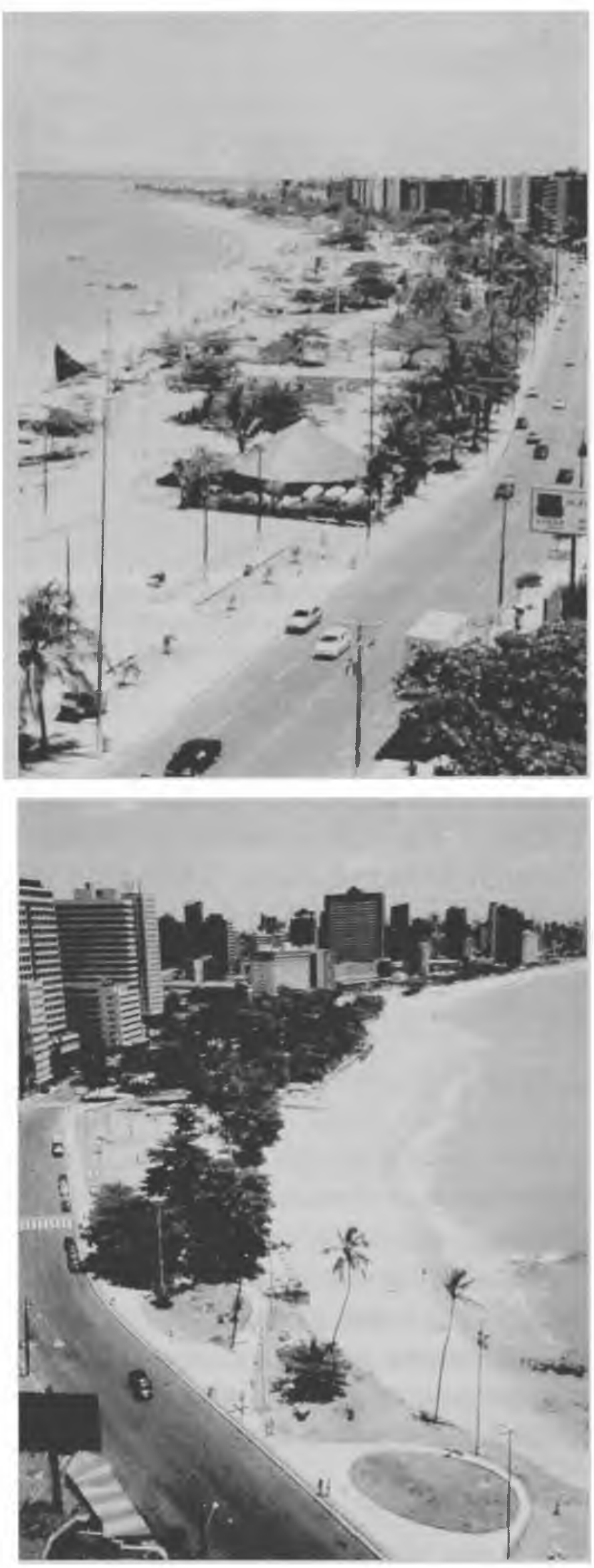

Fotos 4 e 5: Calçadão da Praia de Pajuçara, Maceió Fonte: MACEDO. S. S. CD-ROM QUAPÁ 
O Parque del Litoral em Barcelona, obra do escritório do arquiteto catalāo Oriol Bohigas, é um dos mais reputados exemplos dessa modalidade de parque. Situado entre o centro da cidade, o porto e a nova área habitacional construída para atender os Jogos Olímpicos de 1992, o Parque del Litoral foi concebido como um conjunto de espaços livres públicos que funcionasse como um novo foco de lazer e de turismo, numa área até entāo ocupada por obsoletas instalações industriais, mas que também redefinisse as conexões da cidade com o mar (Figura 6).

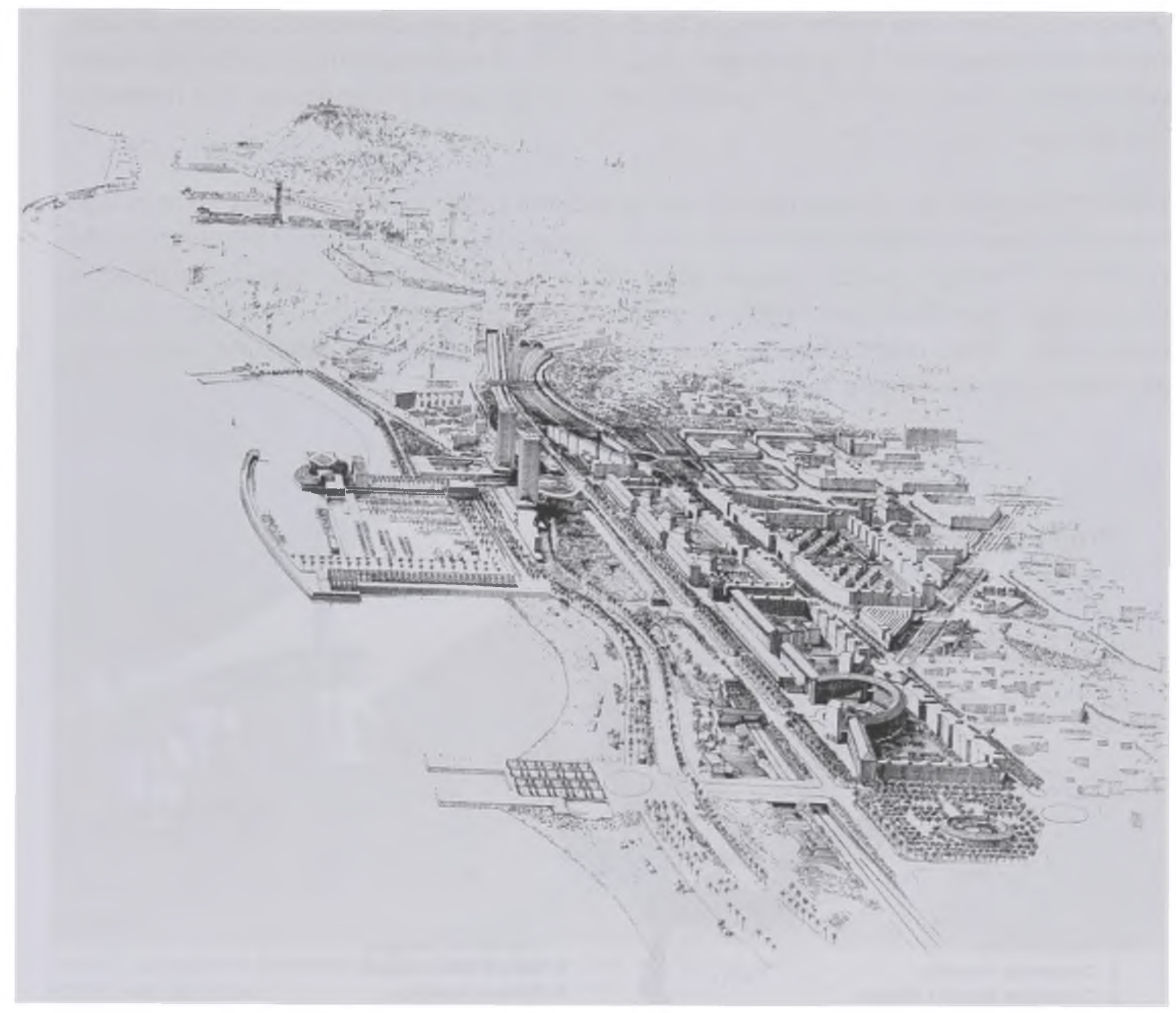

Figura 6: Parque del Litoral, Barcelona Fonte: ROLDEN, R., 1996, p. 75 
A positiva repercussão dessas experiências tem incentivado iniciativas similares em diferentes contextos. Tal é o caso do Projeto Orla, situado às margens do lago Paranoá, em Brasília, que ao contrário das experiências citadas, não foi pensado com o sentido de revitalizar áreas industriais ou portuárias decadentes, mas sim de dinamizar as atividades do setor turismo na cidade. A idéia é que com isso se consiga gerar empregos e renda no setor privado, como alternativa à excessiva concentração de postos de trabalho na administração pública ${ }^{15}$. Outra justificativa usada na defesa do Projeto Orla é que a cidade se encontrava separada do lago e era preciso fazer uma melhor integração da cidade com ele, oferecendo opções de lazer público às suas margens, já que, em grande parte, elas se encontravam ocupadas por clubes particulares e residências, ou sem qualquer infra-estrutura que possibilitasse uma utilização mais generalizada.

Projetado para dar uso a uma faixa de terras públicas desocupadas, situadas entre o lago Paranoá e o chamado Plano-Piloto - área urbana planejada por Lúcio Costa - o Projeto Orla foi concebido como um grande parque linear composto de 11 pólos, cada um com uma programação específica, com hotéis, resorts, marinas públicas, museus, centros culturais, restaurantes, cafés, quiosques etc., que estariam interligados por faixas de vegetação, calçadōes e ciclovias (Figura 7).

\section{Projeto Orla (Brasilia, DF)}

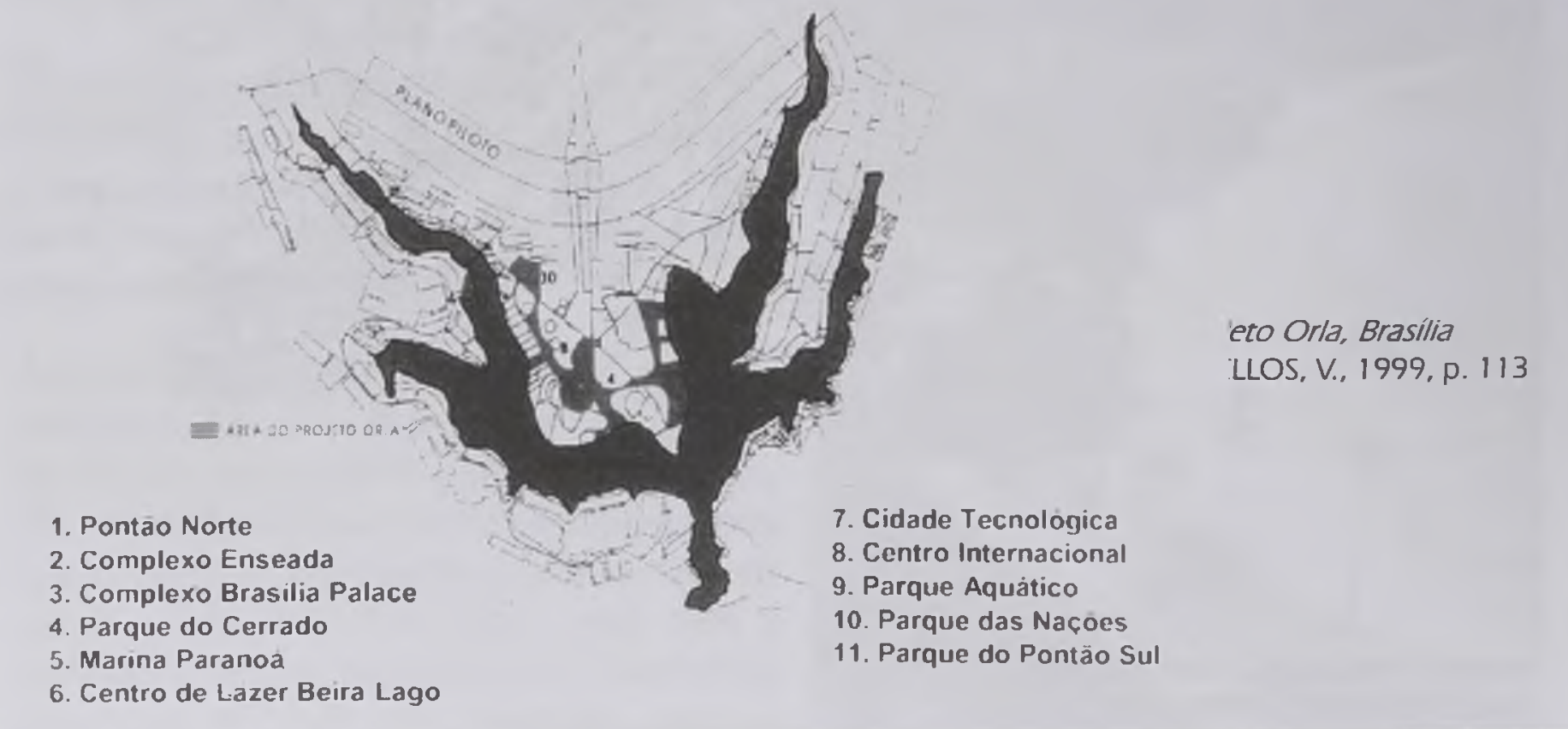

(15) Por ter sido concebida como uma capital, exclusivamente política e administrativa, sempre houve muita resistência à instalação de indústrias no Distrito Federal. Paradoxalmente, sua população estimada em 2 milhões tem a maior renda per capita brasileira e, nos últimos anos, tem tido um dos mais altos índices de desemprego do país. 
Como se trata de um projeto de grande envergadura, que está sendo implementado pelo setor público em parceria com o setor privado, portanto sujeito à conjuntura política e econômica, não há previsão para a conclusão das obras. No momento, dos 11 pólos previstos apenas dois encontram-se em construção, sendo que, parte de um deles - o pólo 3, já foi aberto ao público. Na realidade, trata-se apenas de um trecho do calçadão previsto com alguns quiosques, estando as demais obras desse pólo em diferentes estágios de execução ${ }^{16}$ (Figuras 8, 9, 10 e 11).

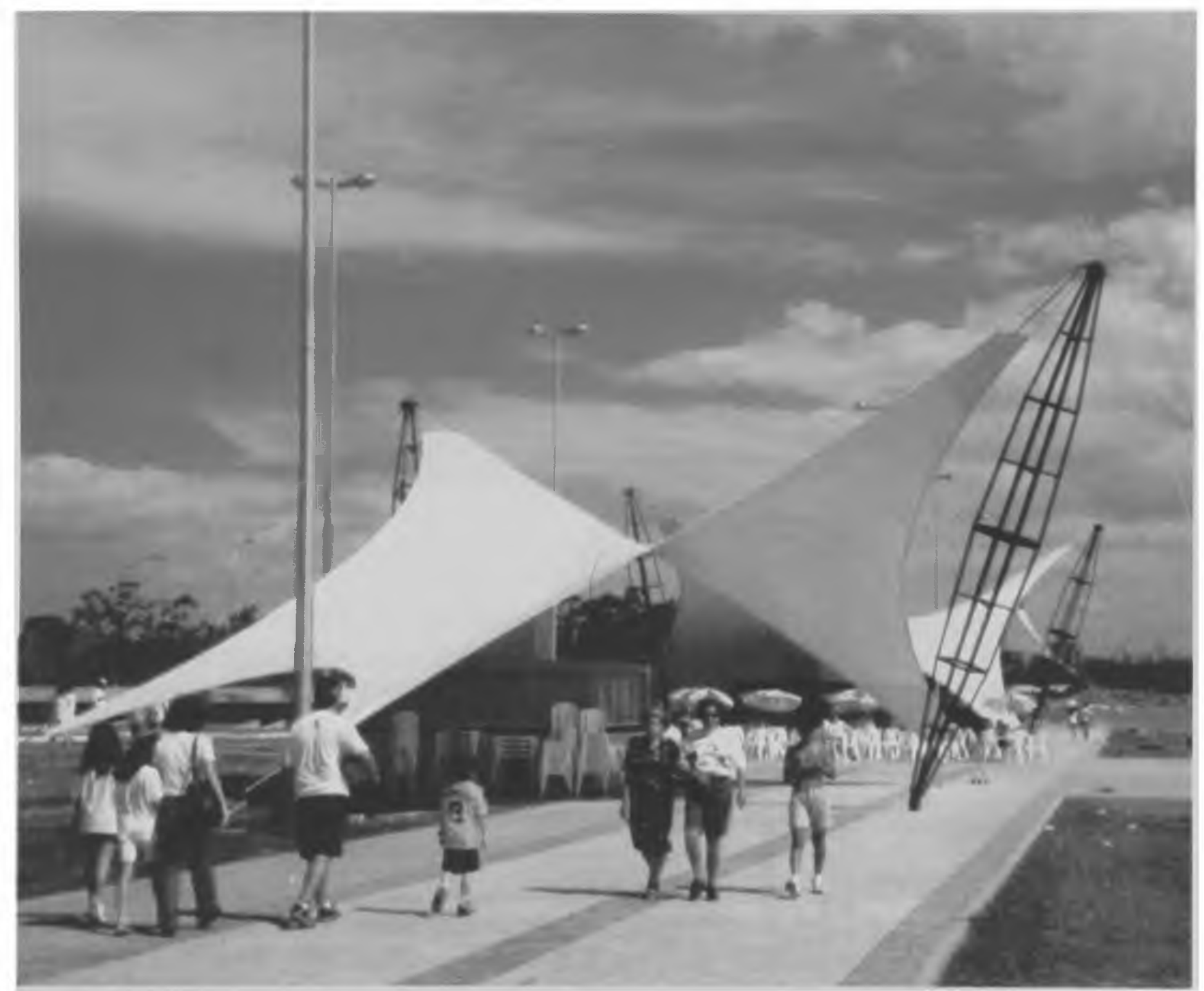

Foto 8: Calçadão do Complexo Brasília Palace, Projeto Orla

Fonte: Foto do autor

(16) Nos dois pólos citados, as obras a cargo da iniciativa privada estão sendo executadas; entretanto, as obras de responsabilidade do setor público pouco têm andado, o que tem sido explicado por razōes políticas, já que o Projeto Orla ficou marcado como obra da administraçāo anterior que licitou os primeiros dois pólos e inaugurou o Complexo Brasília Palace. Como evidência disso, nenhuma iniciativa significativa foi tomada com relação ao projeto. Ao invés disso, a atual administração partiu para uma pouco planejada revitalização do Parque da Cidade, localizado do lado oposto do Plano-Piloto. 

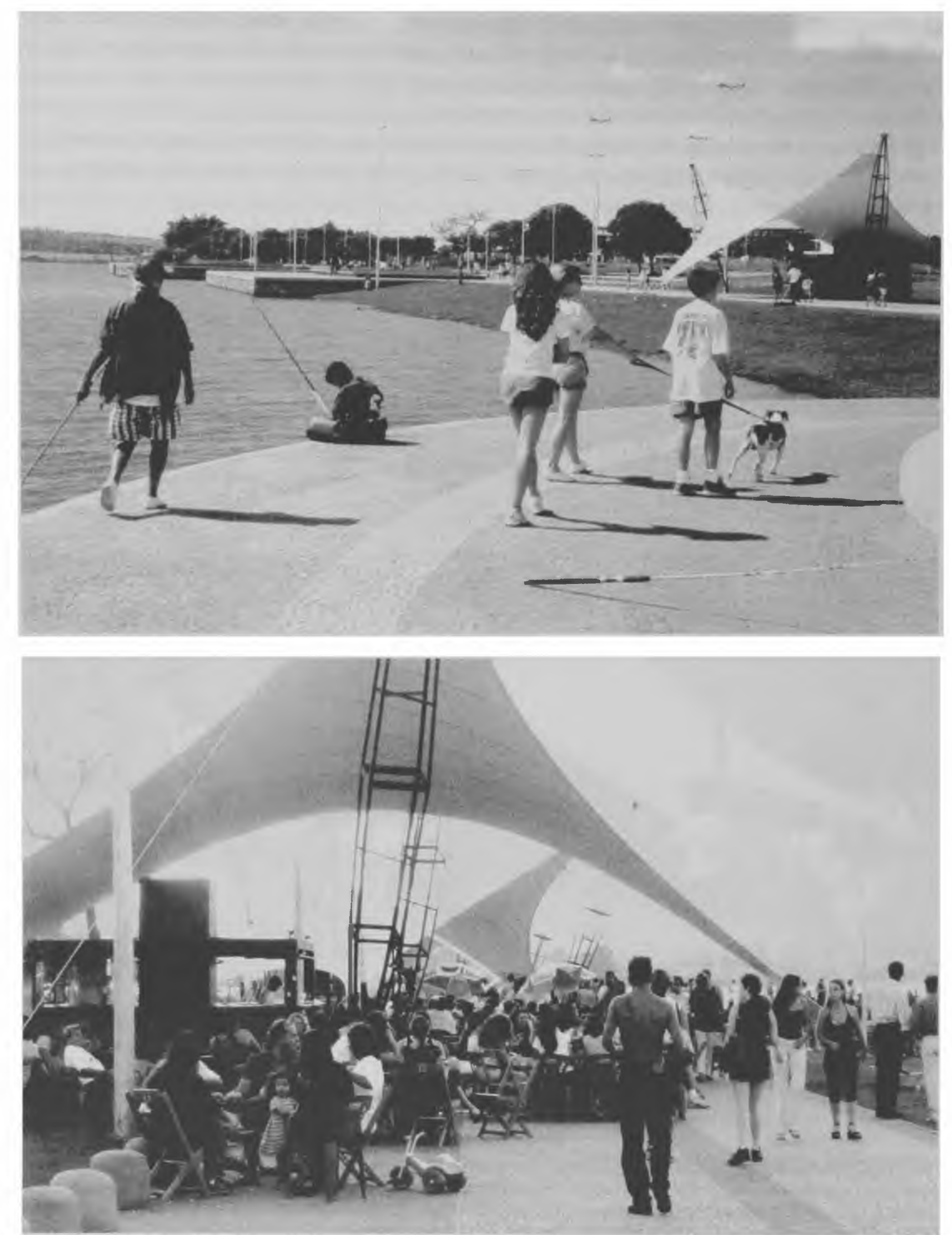

Fotos 9 e 10: Calçadão do Complexo Brasília Palace, Projeto Orla Fonte: Fotos do autor

\section{Paisagem} Ambiente Ensaios 


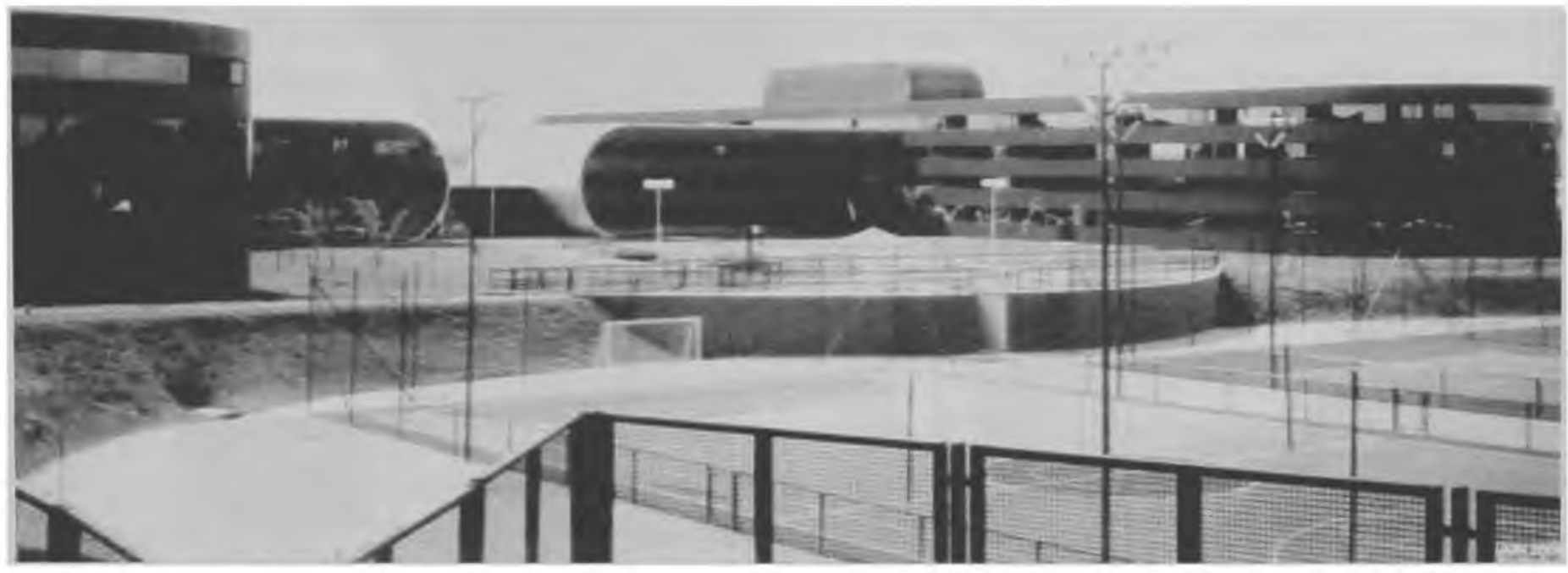

Foto 11: Um dos hotéis do Complexo Brasília Palace, Projeto Orla Fonte: Foto do autor

O Projeto Orla apresenta peculiaridades que não se devem apenas a sua exígua linha de contato com a água, mas ao agenciamento dos seus espaços livres que foram concebidos como públicos. Em função dos objetivos de gerar emprego e renda, no seu interior foram localizados lotes para grandes empreendimentos privados (hotéis, restaurantes, shoppings de lazer etc.), numa solução que o aproxima dos parques temáticos, embora se trate de um parque público. Por outro lado, e talvez até como meio de atenuar essa inclinação comercial, procurouse imprimir um caráter científico e cultural, distribuindo, por quase todos os pólos, equipamentos culturais. Alguns trechos, como o pólo 5 (Museu do Cerrado) e o pólo 7 (Cidade Tecnológica) foram especificamente definidos como centros de atividades científicas e culturais, numa evidente inspiração na experiência do La Villete.

Embora o Projeto Orla tenha sido concebido como um conjunto de espaços livres públicos, o pólo 11, situado às margens do lago Paranoá no setor residencial conhecido como lago Sul pensado como um pólo de restaurantes e bares - durante o seu processo de implementação acabou sendo licitado para ser totalmente construído e explorado pela iniciativa privada. Surpreendentemente, os investidores resolveram construir na entrada do pólo um "arco romano", que gerou grande polêmica na cidade, sendo atacado por defensores e detratores de Brasília, que propōem a sua derrubada por considerarem a obra incompatível com os padrões arquitetônicos e urbanísticos de Brasília (Foto 12). 


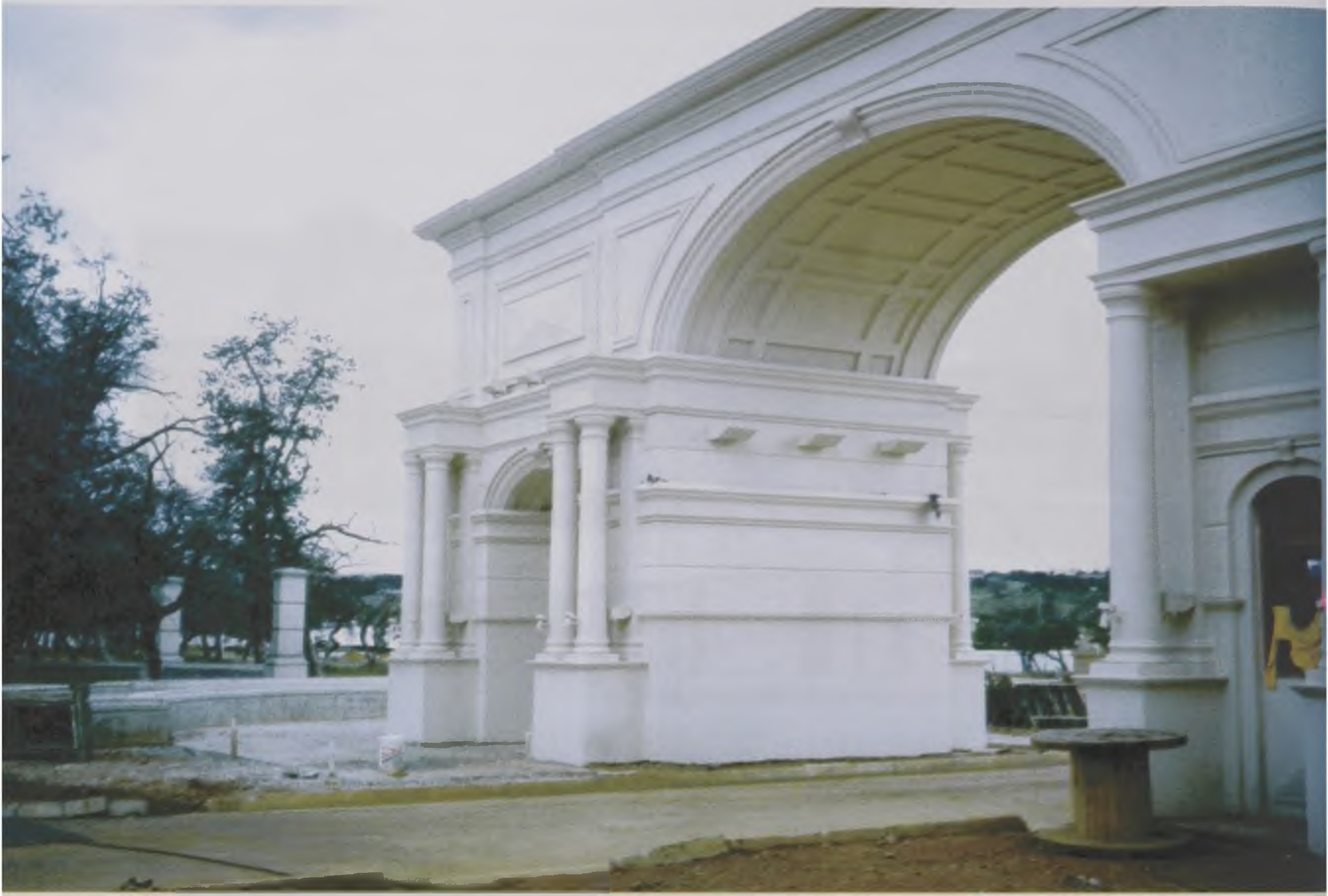

Foto 12: Entrada do pólo 11 (Pontão Sull do Projeto Orla, Brasília

Fonte: Foto do autor

O que o Projeto Orla evidencia, e de certo modo o La Villete também, é a influência dos parques temáticos (privados) no modo de se pensar os parques públicos. Embora de linhagens distintas, o parque público e o parque temático têm uma origem comum: o jardim do palácio. Enquanto o parque público, em sua origem, é fruto do desconforto social das elites burguesas nas tumultuadas cidades européias sob impacto das transformaçōes proporcionadas pela implantação da ordem mercantilista, portanto de um anseio que contrapõe ao ambiente urbano uma paisagem natural idealizada que funciona como palco de sociabilidade da burguesia, na busca pela hegemonia nas cidades, o parque temático provém de uma linhagem menos elitizada. Ele é uma evolução do velho parque de diversōes, o qual, como sugere Lewis Munford, tem origem no jardim de prazer ( pleasure gardens) dos séculos 17 e 18, que, com seus pavilhões de dança, jardins e bosques com recantos para os jogos amorosos, gangorras e carrocéis, proporcionavam a preços módicos por cabeça, folguedos e prazeres antes restritos à corte nos jardins dos palácios ${ }^{17}$.

(17) MUMFORD (1982, p. 411 ). 
Assim, ao contrário do que somos levados a pensar, o parque temático não é fruto apenas do avanço da cultura de massa, das inovações tecnológicas e das novas estratégias da indústria do lazer e do entretenimento no cenário da globalização capitalista, mas também da longa e descontínua evolução dos parques privados. Embora nos países desenvolvidos os parques privados tenham consolidado uma tradição, e assim permanecido, no contexto brasileiro, até o surgimento dos primeiros parques temáticos na década de 80 , havia apenas uns poucos zoológicos privados (concentrados na região Sudeste), além dos parques de diversões que perambulavam pelas cidades, sem se fixarem.

Mas a partir dos bem-sucedidos empreendimentos da Flórida, que extrapolando o âmbito americano forjaram um importante destino turístico numa regiāo sem maiores atrativos, os parques públicos que até então eram concebidos como uma paisagem que evocava a natureza e como locus de lazer e de práticas esportivas descompromissadas, passam a ser percebidos por suas possibilidades de dinamização da economia urbana e na melhoria ou reforço da imagem das cidades.

O uso dos parques públicos nesse último sentido não chega a ser novidade. Alguns dos mais clássicos exemplos de parques paisagísticos, já desde muito, vinham sendo explorados com esses mesmos objetivos, é só lembrar da importância do Central Park de Nova York ou dos parques de Londres na constituição da imagem dessas cidades e do significado deles para o turismo, tanto em termos de atração de fluxos como em termos de tempo de estada. O que há de novo é o sentido de eficiência que se procura imprimir aos parques públicos.

A influência do parque temático (por mais paradoxal que possa parecer) manifesta-se também no parque ecológico - modalidade de parque público que, a partir da década de 70 , com a emergência da questāo ambiental, passa a ser disseminado nas cidades. Enquanto unidade de conservação aberta ao uso da população para limitadas práticas de lazer, o parque ecológico, pensado como reserva verde que devia ser deixada ao sabor dos processos naturais, na década de 90 tende a passar por uma reengenharia que fazcom que, em alguns casos, ele adote elementos os quais seriam próprios da cultura de consumo, em aparente contradição com o ideário ambientalista que os disseminaram. Mas, pelo menos nesse caso, não se trata de uma simples concessão ao gosto popular, mas sim de uma estratégia que parte da premissa de que a conservação de tais espaços em áreas sob pressão dos processos de urbanizaçāo, só é viável se ele atrair e se mostrar útil à populaçāo que, a partir daí, passaria a defendê-lo de depredações, da especulação imobiliária e das eventuais invasões de seus espaços.

O exemplo mais notável de incremento de uma rede de parques públicos a partir das preocupações ambientais está em Curitiba. Aí eles resultaram de um bem estruturado esforço de planejamento, que tem como motivação inicial a conservação dos remanescentes florestais, e dos fundos de vales em seu papel no controle de enchentes e outras áreas identificadas como ambientalmente sensíveis - em muitos casos, antigas jazidas de exploração mineral desativadas. 
Reforçar a finalidade comunitária de tais espaços e assim envolver a população nas tarefas de conservação - em especial aquelas relacionadas à manutenção dos limites físicos. Com esse objetivo foram localizados nos parques equipamentos públicos de fins culturais ou construções de caráter simbólico, cujo sentido é servir de foco de atração para a comunidade. Em alguns casos, tratam-se de grandes infra-estruturas, como o caso do Parque da Pedreira, onde se encontra a Ópera de Arame, um teatro com 2.600 lugares e um espaço para grandes eventos ao ar livre que comporta cerca de 10 mil pessoas. Em outros casos, são construções de menor porte, como o centro de atividades artísticas do Parque São Lourenço ou a sede da Universidade Livre do Meio Ambiente (na verdade um centro de estudos do meio ambiente) do Bosque Zaninelli.

Em consonância com as preocupações ambientais, o tratamento dado aos parques, pelo menos inicialmente, procurava escapar de toda e qualquer sugestão de ajardinamento e se resumia a extensos gramados interrompidos por massas de vegetação pontuadas por árvores nativas, caminhos e algum mobiliário. Com idéia de negar o ajardinamento, a construção dos parques baseava-se, segundo seus autores, num plano geral de açāo que ia sendo adaptado durante a implementação, inclusive, com a retirada e relocação de plantas ${ }^{18}$

Na verdade essa atitude, propalada como "sem projeto paisagístico" - como se o projeto paisagístico fosse sinônimo de elaborações formais - não chega a constituir novidade, mesmo porque, a economia no trato da vegetação nos parques é uma tradição que tem raízes no landscape gardering dos ingleses no século 18, desenvolve-se com Frederick Law Olmsted e é incorporada e adaptada por amplos setores da arquitetura paisagística moderna. O que há é apenas uma radicalização de discurso, nos moldes do movimento arquitetura sem arquitetos ${ }^{19}$ da contracultura da década de 70, que parte do princípio de que o abandono do projeto e de toda racionalidade que Ihe é inerente, produziria um resultado mais naturale portanto, mais de acordo com as preocupações ambientalistas.

Mas essa atitude ideologicamente rigorosa acabou evoluindo para uma solução híbrida e contraditória que ao buscar uma maior empatia popular, acaba conciliando o tratamento de aparência naturalista com trechos de canteiros de bordaduras floridas ao estilo do jardim formal francês, que se afasta de tudo o que possa parecer natural, mesmo porque, são produzidos a partir de sementes alienígenas e mantidos com intensivo uso de adubos. Com precisão, Sílvio Macedo descreve esse tratamento como uma ruptura, que se apresenta como uma característica pós-moderna, na qual os velhos princípios e formas do ecletismo não são mais renegados, passando a ser reincorporados nos projetos dos parques de Curitiba, produzindo uma cenarização da paisagem ${ }^{20}$ (Foto 13).

(19) As idéias da arquitetura sem arquitetos tiveram na Califórnia seu principal centro de irradiaçāo e foram em grande parte difundidas pelo livro Handmade houses: A guide to the woodbutcher's art, de Boericke e Shapiro (1973).

(20) MACEDO (1999, p. 103-114). 


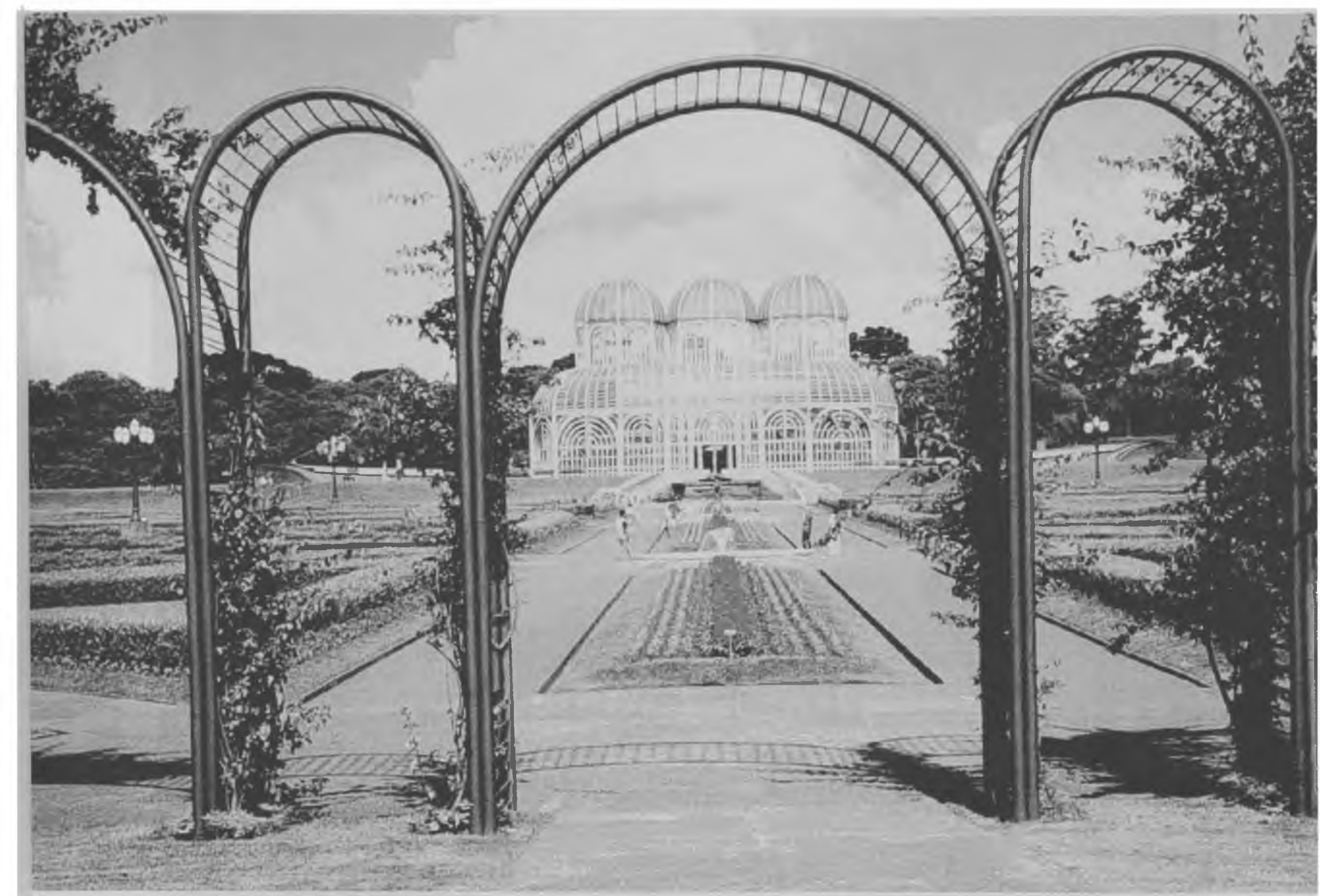

Foto 13: Jardim Botânico de Curitiba. Sua estufa é hoje o principal cartão-postal da cidade

Fonte: Foto do autor

Ainda que se possa criticar essa combinação de concepções de princípios tão antagônicos, a solução teve uma grande aceitação popular e realiza, portanto, a pretendida interação da população com os parques.

Do mesmo modo, a inventiva arquitetura que marcava os primeiros parques de Curitiba foi aos poucos sendo substituída por construçōes de maior impacto, de evidente gosto pós-moderno, como a estufa do Jardim Botânico, a aldeia de cabanas de tronco do Bosque do Papa, a igreja do Memorial Ucraniano do Parque Tinguí, ou o castelo sobre a cascata do Parque Tanguá (Fotos 14, 15, 16 e 17).

Os resultados de todo esse trabalho que vem sendo realizado nos parques de Curitiba ao longo tempo, e que só agora parece consolidado, têm sido eficientemente explorado pela prefeitura, que com uma linha de ônibus especial (tipo jardineira), transformou os mais importantes parques da cidade em cotados pontos turísticos, uma solução ímpar no contexto das cidades brasileiras. 


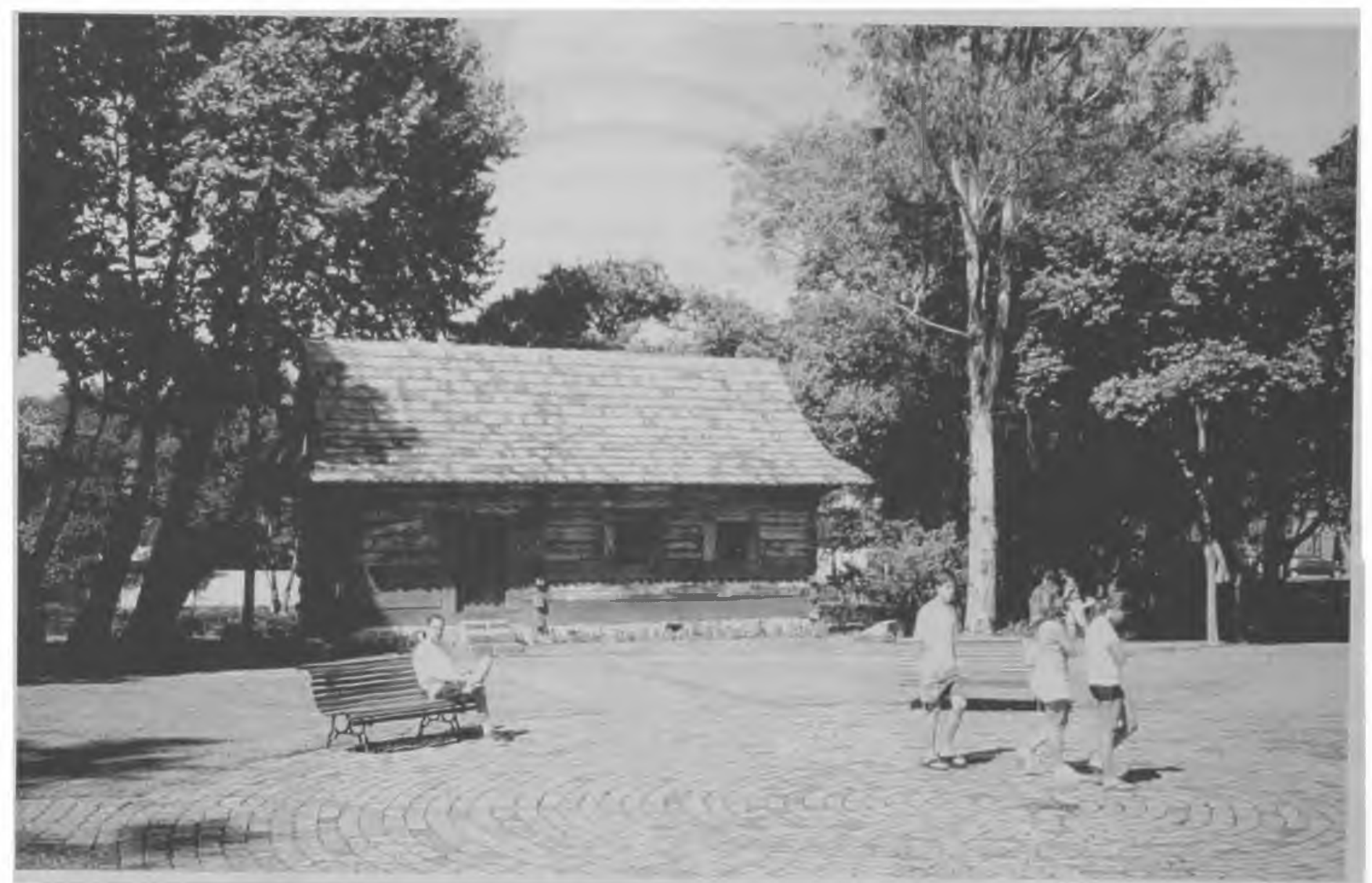

Foto 14: Aldeia do Bosque do Papa, Curitiba

Fonte: Foto do autor

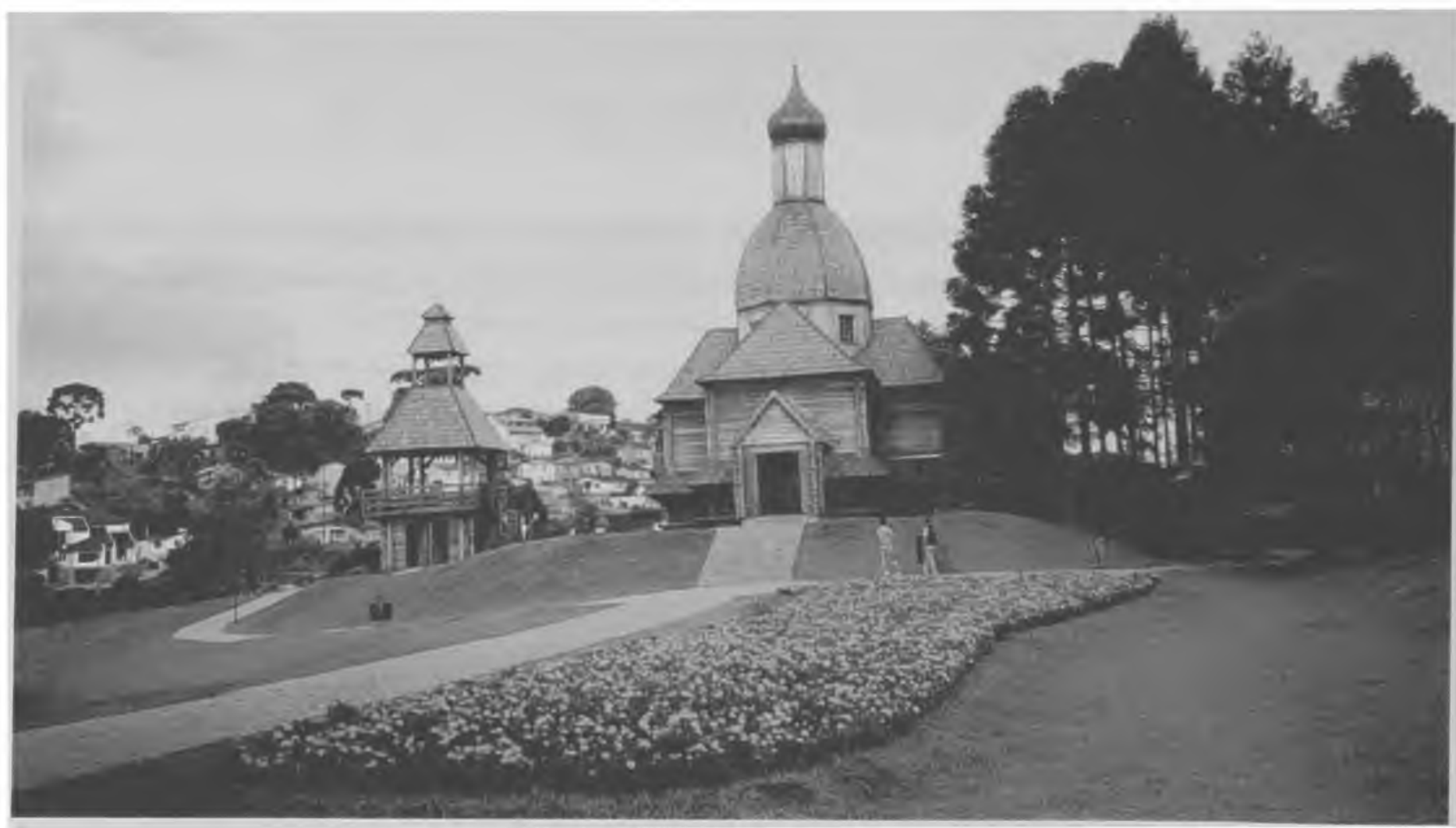

Foto 15: Memorial Ucraniano no Parque Tinguí, Curitiba

Fonte: Foto do autor 


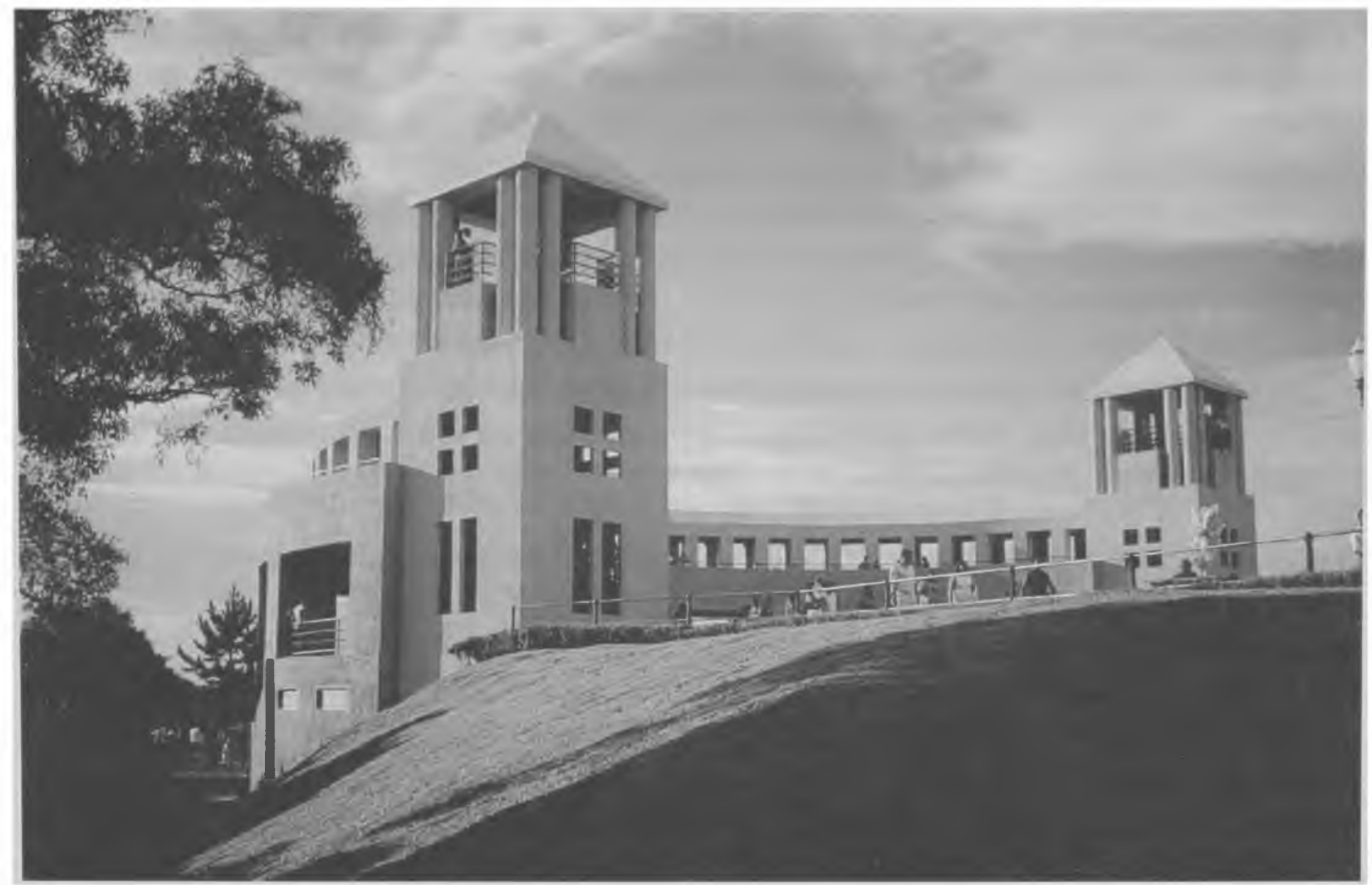

Foto 16: Castelo do Parque Tangúa, Curitiba

Fonte: foto do autor

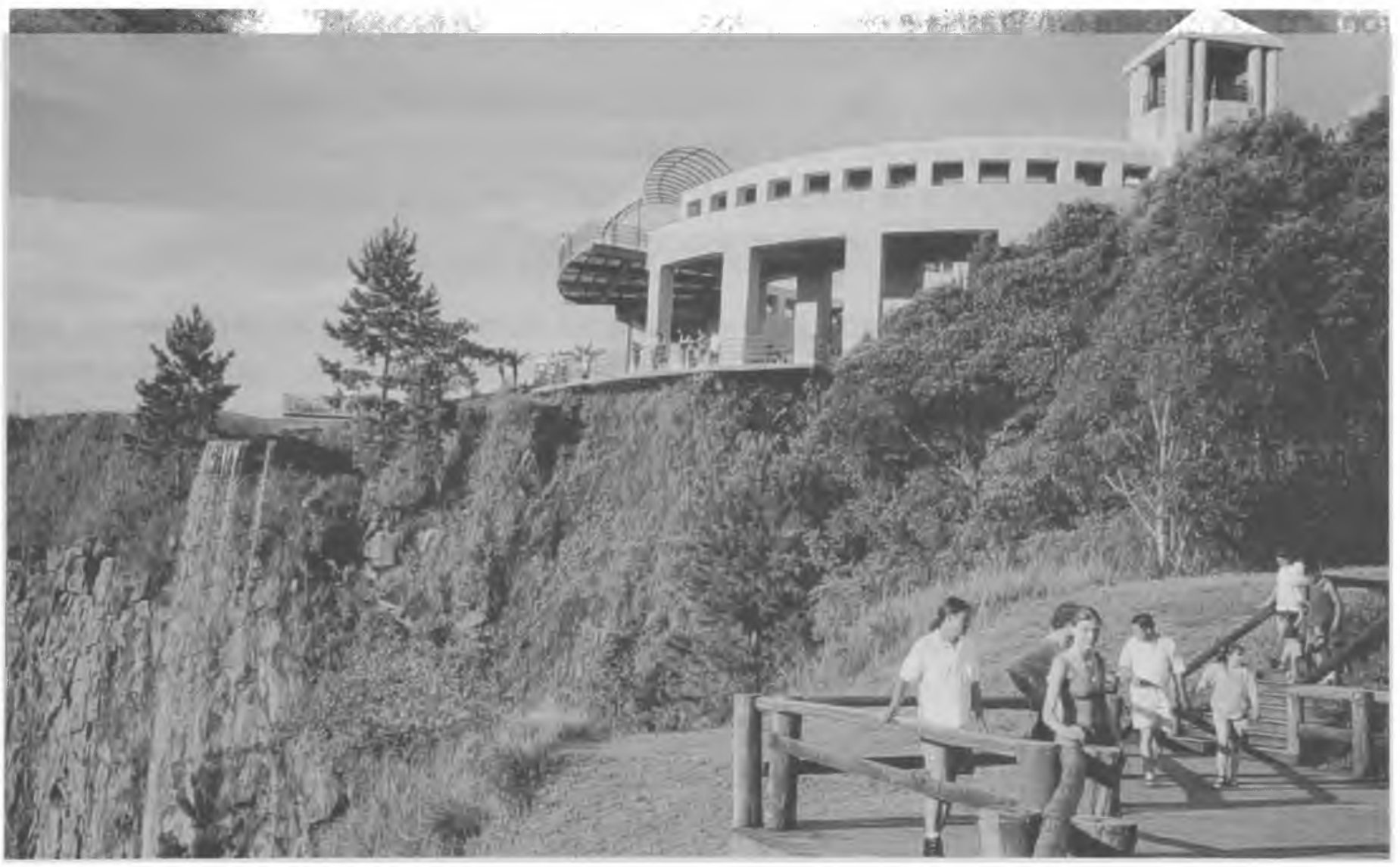

Foto 17: Castelo do Parque Tangúa, Curitiba

Fonte: Foto do autor 
Por sua repercussão, essa e quase todas as soluções urbanas adotadas em Curitiba têm sido sempre muito criticadas. De modo geral, a alegação é que se trata de simples marketinge não efetivas soluções para os problemas da cidade. De fato, elas podem merecer reparos, mas as críticas parecem sempre despropositadas, principalmente se comparamos o nível de organização dos serviços públicos urbanos oferecidos à população de Curitiba, com o da maioria das cidades brasileiras. No caso específico das soluções dadas aos parques, além dos benefícios decorrentes do turismo, tanto em termos de geração de emprego quanto de renda, eles fizeram dos parques prestigiados espaços de lazer da população, ao mesmo tempo que tornaram viável a conservação ambiental, ainda que na ortodoxia da visão ambientalista, os usos dados aos parques e os padrões de comportamento dos usuários possam parecer inconvenientes.

O que os parques de Curitiba e o Projeto Orla de Brasília evidenciam, cada um a seu modo, é a entrada do parque no foco do desenvolvimento urbano no contexto brasileiro, como parte de uma busca de alternativas que contribuam para dinamizar as economias locais. Entretanto, o que não tem sido claramente percebido nesse processo é a penetração no âmbito dos parques públicos de uma lógica que é mais própria aos empreendimentos privados, com todas as suas conseqüências, tanto as positivas, como a procura de dar eficiência aos bens e serviços que são oferecidos à população, quanto as negativas como as tendências de estimular aquelas práticas de lazer mais massificadas e comercializáveis e de alijar segmentos sociais que não se enquadram nessa perspectiva. E em alguns casos, o não-entendimento da diferença entre a lógica do empreendimento público e do privado tem gerado conflitos e imprevistos. $O$ "arco romano" construído em Brasília é exemplo disso.

As preocupações com o turismo e com as questões ambientais têm propiciado o surgimento de um grande número de parques nas cidades brasileiras. Entretanto, como bem observa Macedo, a maioria dos projetos de parques não tem sido vinculada a ações de planejamento que articulem sua construção com as necessidades sociais ${ }^{21}$

No caso dos parques surgidos a partir das preocupações com o turismo, evidentemente, eles acabam sendo criados nas áreas urbanas mais ricas e valorizadas, onde se concentra a maior parte das opções de lazer e recreação das cidades. No caso dos parques ecológicos, a tendência é inversa, já que costumam ser situados nas periferias urbanas que, em geral, são ocupadas por populações de baixa renda. Entretanto, pelo fato de eles surgirem de preocupações ambientais, como a conservação de remanescentes de vegetação nativa consideradas ameaçadas pelos processos de urbanização, no seu planejamento, as condições de acesso da população acabam quase sempre sendo esquecidas, embora se situem em locais em que populações empobrecidas dispõem de poucas opções de lazer. O resultado é que o surgimento de novos parques nas cidades brasileiras, muitas vezes, ao invés de representarem uma maior democratização das oportunidades de lazer e recreação, tem contribuido para agravar as desigualdades que marcam as cidades brasileiras.

(21) MACEDO (1999, p. 91). 


\section{Bibliografia}

ARANTES, Otília. O lugar da arquitetura depois dos modernos. São Paulo: Studio Nobel, 1993.

BARCELLOS, Vicente. Os parques como espaços livres públicos de lazer: O caso de Brasilia. São Paulo, 1999. Tese (Doutorado). Faculdade de Arquitetura e Urbanismo, Universidade de São Paulo.

Alocação de parques urbanos no campo empírico do Distrito Federal. In: II ENEPEA - II ENCONTRO NACIONAL DE ENSINO DE PAISAGISMO EM ESCOLAS DE AROUITETURA E URBANISMO DO BRASIL, São Paulo. Anais. São Paulo: Universidade São Marcos - FAUUSP, 1996.

BOERICKE, Art, SHAPIRO, Barry. Handmade houses: A guide to the woodbutcher's art. San Francisco: A\&W Visual Library. 1973.

BONGESTABS, Domingos H. Universidade Livre do Meio Ambiente. In: Visōes da paisagem: Um panorama do paisagismo contemporâneo no Brasil. São Paulo: ABAP - Associação Brasileira de Arquitetos Paisagistas, 1997.

COSTA, Lúcia. M. S. A. Popular values for urban parks: A case study of the changing meanings of Parque do Flamengo in Rio de Janeiro. Londres, 1993. Tese. University College of London.

CRANZ, Galen. Four models of municipal park design in the United States. In: Denatured visions: Landscape and culture in the twentieth century. Nova York: MoMa, 1991.

GALENDER, Fany. Consideraçōes sobre a conceituaçāo de espaços públicos. Paisagem e Ambiente: Ensaios. Sāo Paulo: FAUUSP $\quad$ n. 4, p. 113-120, 1992.

HOLDEN, Robert. Diseño del espacio publico internacional. Barcelona: Gustavo Gili, 1996.

MACEDO, Silvio Soares. Ouadro do paisagismo no Brasil. São Paulo: FAUUSP, Coleçāo QUAPÁ. 1999.

Paisagismo brasileiro, guia de parques e praças. CD-ROM QUAPÁ - Semiotic Systems. Sāo Paulo, s/d.

MARTIN, Hervé. Guide de l'architecture moderne à Paris. Paris: Èditions Alternatives, 1991.

MARX, Murillo. Cidade brasileira. Sāo Paulo: Melhoramentos, 1980.

MUMFORD, Lewis. A história na cidade: Suas origens, transformaçōes e perspectivas. São Paulo: Martins Fontes, 1982.

SENNETT, Richard. O declínio do homem público: As tiranias da intimidade. Sāo Paulo: Companhia das Letras, 1998.

ZOOPI, Mariella. Progettare com il verde. Manuale di progettazione del verde e dei vuoti urbani. Firenze: Alinea Editrice, 1996. 